\title{
Особливості хірургічного лікування вогнепальних поранень живота
}

\author{
І. П. Хоменко ${ }^{1}$, О. С. Герасименко ${ }^{2,3}$, Р. В. Снін ${ }^{2}$, А. М. Галушка ${ }^{1}$, А. П. Казмірчук
}

${ }^{1}$ Національний військово-медичний клінічний центр МО України, м. Київ,

${ }^{2}$ Військово-медичний клінічний центр Південного регіону, м. Одеса,

${ }^{3}$ Одеський національний медичний університет

\section{Peculiarities of surgical treatment of the abdominal gun-shot woundings}

\author{
I. P. Khomenko ${ }^{1}$, O. S. Herasymenko ${ }^{2,3}$, R. V. Yenin ${ }^{2}$, A. M. Halushka ${ }^{1}$, A. P. Kazmirchuk ${ }^{1}$ \\ ${ }^{1}$ National Military-Medical Clinical Centre, Kyiv, \\ ${ }^{2}$ Military-Medical Clinical Centre of Southern Region, Odessa, \\ ${ }^{3}$ Odessa National Medical University
}

\begin{abstract}
У структурі сучасної бойової травми зростає частка пошкоджень органів черевної порожнини, які супроводжуються розвитком травматичного шоку, поліорганної недостатності та високою летальністю. Трирічний досвід збройного конфлікту на сході України показав, що сучасна зброя - реактивні системи залпового вогню, касетні бомби, керовані вибухові пристрої високоточної дії тощо - завдає особливо тяжких поранень. Структура бойової травми живота залежить від характеру ведення бойових дій, який останніми роками також значно змінився, тому потрібні нові підходи до діагностичних заходів та хірургічного лікування.

Частота поранень живота в загальній структурі бойо-
\end{abstract} вих пошкоджень коливається від 6,6 до 9\% [1 - 3], за даними АТО в середньому становить 4 - 7\% [4 - 7]. Через тісний взаємозв'язок результатів лікування поранень живота $з$ термінами початку та якістю хірургічної допомоги, з термінами та видом медичної евакуації з різних рівнів надання медичної допомоги виникають великі організаційні труднощі, особливо у разі масового надходження поранених. Специфічні ознаки вогнепальних поранень живота обумовлюють особливу тяжкість функціональних розладів, більш частий розвиток ускладнень (54 - 81\%) i, як наслідок, більш високу летальність (12 - 31\%) [8 - 11].

Повідомляється про зниження летальності серед військовослужбовців, поранених у живіт, в останніх локальних конфліктах і одночасне зростання частоти пошкодження органів живота - селезінки, нирок, тонкої і товстої кишок, шлунка [4 - 6, 12], що обумовлено широким застосуванням автоматичної стрілецької зброї зі значною уражаючою дією, а також подальшим вдосконаленням бойових якостей снарядів, мін і гранат $[4,8]$.

Частота поранень живота під час військових операцій в Іраку й Афганістані за даними медичної служби коаліції варіювала від 8 до 17\%. Причиною загибелі 70\% військовослужбовців була вибухова травма [13].

Вогнепальні поранення живота отримували військовослужбовці під час війни в Кореї, В'єтнамі, арабо-ізраїльських та інших локальних військових конфліктів.
Наданню допомоги військовослужбовцям, пораненим у живіт, присвячено ряд монографій останніх десятиліть $[4,9,13]$. Однак деякі питання хірургічної тактики залишаються дискусійними.

Більшість авторів вважає, що абсолютними показаннями до оперативного лікування поранень живота є евентерація внутрішніх органів, внутрішньочеревна кровотеча і наявність ознак перитоніту. В сучасних умовах при пораненнях живота застосовують ультразвукову діагностику (УЗД) за FAST-протоколом (focused abdominal sonography for trauma), що дає змогу достовірно визначити як наявність, так і об'єм рідини в черевній порожнині [14 - 20]. Комп'ютерна томографія (КТ) дає можливість не тільки визначити наявність рідини в черевній порожнині, а й оцінити характер і обсяг пошкодження органів черевної порожнини [20, 21], але іiі проведення можливо не на всіх рівнях надання медичної допомоги. Використання цих методів дає змогу, на думку багатьох хірургів, у 20 - 25\% поранених відмовитися від лапаротомії та проводити динамічне спостереження за ними $[22,23]$. Альтернативою $є$ застосування ендовідеохірургічних методик, зокрема лапароскопіі [7, 24].

При пораненнях шлунка виконують первинне ушивання стінки двохрядним швом, а в разі його розтрощення резекцію шлунка. Особливо наголошують на необхідності ревізії задньої стінки шлунка $[4,5,25]$ шляхом розсічення шлунково-ободової зв'язки. Після ушивання шлунка виконують пробу на герметизм - заливають у черевну порожнину рідину та вводять за допомогою мішка Амбу повітря через шлунковий зонд, поява в рідині пухирців повітря вказує на недостатню герметичність або наявність інших пошкоджень [6].

Пошкодження дванадцятипалої кишки (ДПК) часто не виявляють навіть під час оперативного втручання, що обумовлено особливістю анатомічного розташування органа. Необхідно мати на увазі ймовірність ії пошкодження, якщо ранячий снаряд або рановий канал знаходяться в зоні ДПК, а також якщо є кров у виділеннях із назогастрального зонда та імбібіція кров'ю або жовчю заоче- 
ревинної клітковини. Виділяють три типи пошкодження ДПК: інтрамуральна гематома, непроникаюче поранення; перфорація або розрив тільки ДПК; панкреатодуоденальні пошкодження [26]. Поранення, які проникають в просвіт ДПК, становлять 95\% всіх іiі пошкоджень [25, 27]. Більш ніж у 90\% спостережень пошкодження ДПК поєднуються 3 пошкодженнями інших органів черевної порожнини [28]. Невеликі пошкодження цибулини або верхньої горизонтальної частини ДПК достатньо ушити двохрядним швом та дренувати черевну порожнину. Якщо виявлено дефект, що перевищує 50\% окружності ДПК, або повний iii розрив, виключають (дивертикулізація) ДПК, прошивши пілородуоденальний перехід апаратом УКЛ, та формують гастроентероанастомоз на довгій петлі за Бальфуром 3 міжкишковим анастомозом за Брауном. У разі пошкодження ДПК у ділянці великого сосочка обов'язково виконують зовнішнє дренування жовчовивідних шляхів (формують або холецистостому, краще черезшкірно черезпечінково, або холедохостому за Піковським) [1, 3, 5, 27].

Хірургічна тактика при пораненнях тонкої кишки (ТК) цілком відпрацьована. Щодо субсерозних гематом і непроникаючих поранень ТК проводять ревізію, виконують мінімальну обробку і первинне закриття окремими вузловими швами. Інтрамуральні крововиливи в стінку ТК потім можуть призвести до перфорації $[2,4,12]$. Необхідна ретельна ревізія всієї ТК від зв'язки Трейтца до ілеоцекального кута з оглядом усіх сегментів з обох боків. Так само показана ретельна ревізія пошкодження брижі біля самого краю ТК, тому що тангенціальні перфорації брижового краю не завжди можливо виявити під час поверхневого огляду. Доцільно застосовувати правило «парних пошкоджень» у лікуванні проникаючих поранень тонкої і товстої кишок. Осколки майже завжди перфорують обидві стінки кишки, тому число отворів у кишці є діагностичним критерієм. Це правило не є абсолютним, але ним варто керуватися, щоб не пропустити пошкодження [2, 7, 9, 15]. Якщо ТК пошкоджена до половини діаметра, показана резекція з анастомозом у три чверті. Показаннями до резекції ТК є множинні рани на обмеженій ділянці кишки, повний перерив кишки, розтрощення стінки, великі розміри і неправильна конфігурація дефекту, поздовжні розриви кишки, рана або велика гематома у брижовому краю кишки, а також відриви від брижі, поперечний розрив брижі з ішемією або некрозом стінки кишки [7, 23, 27]. На летальність зазвичай впливають затримка в діагностиці і лікуванні, ступінь пошкодження ТК, одночасне пошкодження інших органів черевної порожнини.

Хірургічна тактика при вогнепальних пораненнях товстої кишки неоднозначна. Окремі автори пропонують враховувати стан очеревини, час, що минув від моменту травми, розміри ранового дефекту та обширність пошкодження товстої кишки. Дефект стінки кишки менше третини ії окружності ушивають двохрядним швом, більше третини - ушивають та виконують екстраперитонізацію зашитої ділянки, більше половини - виконують обструктивну резекцію за зразком операції Гартмана $[4,9,11]$. У разі розчавлення, численних поранень кишки виконують ії резекцію з колостомією [1 - 3]. При пошкодженні сліпої кишки та висхідного відділу ободової за сприят- ливих умов виконують правосторонню геміколектомію з ілеотрансверзоанастомозом або завершують операцію формуванням стоми $[1-3,10,11]$. При вогнепальних пораненнях внутрішньоочеревинного відділу прямої кишки доцільно виконувати обструктивну резекцію пошкодженої ділянки прямої кишки по типу операції Гартмана. При пошкодженні позаочеревинного відділу прямої кишки перевагу віддають формуванню проксимальної колостоми (через мінідоступ або лапароскопічно) з відмиванням залишків калових мас антисептиками, інтубації прямої кишки і дренуванню параректального простору. При пораненні сфінктера виконують первинну хірургічну обробку з первинним швом анального жому та формуванням проксимальної колостоми [6 - 8,10].

При пораненнях товстої кишки з огляду на дуже високий ризик неспроможності накладених швів і анастомозів особливої ретельності потребує визначення хірургічної тактики, яка описана в численних літературних джерелах $[10,21,29]$.

Успішне хірургічне лікування поранень печінки залежить від відповідності оперативного втручання залученню тих чи інших структур органа. Виділяють глибокі і поверхневі рани, локалізовані на периферії або в центральній частині органа, з помірною або масивною кровотечею. Принципово всі пошкодження печінки розподіляють на три групи: пошкодження, які не потребують оперативного втручання, або пошкодження, які потребують оперативного втручання в межах одного сегмента; пошкодження, які потребують оперативного втручання з залученням двох і білыше сегментів; будь-які пошкодження в поєднанні $з$ пошкодженням печінкових вен [13]. При тяжких пошкодженнях печінки проблемою є профузна кровотеча, масивний гемоперитонеум, пульпіфікація печінкової тканини, метаболічні та гематологічні розлади. Перше і найважливіше завдання лікування пошкоджень печінки - зупинка кровотечі, оскільки гостра масивна крововтрата $€$ причиною смерті 75\% поранених з пошкодженням печінки. Якщо в черевній порожнині є багато крові і кровотеча триває, перетискають печінково-дванадцятипалу зв'язку рукою або м'яким затискачем (прийом Прінгла). У частини поранених з пошкодженням печінки, якщо немає кровотечі, не ушиваючи дефектів, налагоджують просте дренування. Саме такій категорії поранених за можливості проведення УЗД та КТ пропонують неоперативне лікування з наглядом [17].

При пошкодженнях печінки основним методом є ушивання рани вузловими або П-подібними швами, доповнене, якщо пошкодження великих розмірів, біологічною тампонадою сальником, зв'язками або м'язом. При розтрощених пошкодженнях печінки видаляють некротичні тканини, які сприяють виникненню повторної кровотечі, з перев'язкою окремих судин, які кровоточать, і жовчних проток. Резекцію як спосіб лікування пошкоджень печінки застосовують у 10 - 17\% поранених, здебільшого це атипова резекція. Для зупинки тяжкої кровотечі з печінки виконують селективну перев'язку гілок або навіть всю печінкову артерію. Крім того, у разі великої крововтрати для попередження коагулопатії, пов’язаної з реінфузією понад 3 л крові, виконують тимчасову тугу тампонаду рани 
печінки з видаленням тампона через 5 - 7 діб, хоча $є$ хірурги, які заперечують такий метод. Дискутується питання про необхідність дренування жовчовивідних шляхів. Одні автори вважають, що воно показано при масивних пошкодженнях печінки для попередження витікання жовчі з печінкових ходів [10, 30]. На думку інших авторів, дренування жовчовивідних шляхів призводить до збільшення числа інфекційних ускладнень [22]. Важливим є адекватне дренування місця виконання операції еластичною трубкою достатнього діаметра через окремий розріз [2 - 5].

При пошкодженнях жовчного міхура, як правило, виконують холецистектомію. Пошкоджену загальну жовчну протоку відновлюють на Т-подібному дренажі з невеликим діаметром просвіту. В літературі небагато повідомлень про такі спостереження, оскільки через крововтрату більшість цих поранених помирає [2, 7, 11].

Хірургічна тактика при пораненнях селезінки в останні роки активно спрямована на ії збереження [8]. Вважають, що не менше ніж у 50\% спостережень поранень селезінки орган може бути збережений. 3 цією метою більш широко використовують місцеві гемостатичні засоби, ушивання органа із застосуванням спеціальних сіток та аргоноплазмової коагуляції. Однак усі ці методи не використовують на етапах медичної евакуації. Застосовують також «консервацію» селезінки, тобто додатково до ії ушивання або часткової резекції виконують перев'язку селезінкової артерії, враховуючи, що «критичний» 3 точки зору функціональної достатності залишок повинен становити 30 50\% маси селезінки. Така тактика обумовлена тим, що після спленектомії ризик сепсису зростає в 12,6 разу і становить $0,5-2,2 \%$. Проте є й протилежні думки. Спленектомію вважають абсолютно показаною в таких ситуаціях: відрив селезінки від судинної ніжки; розчленування селезінки на ряд фрагментів або ії розчавлення; розрив і декапсуляція; розриви селезінки по лінії воріт; одночасне пошкодження селезінки і порожнистого органа; коагулопатія; вкрай тяжкий стан пораненого [19]. У зазначених ситуаціях деякі автори пропонують виконувати імплантацію селезінкової тканини в кишеню великого сальника для профілактики спленозу. Завжди потрібно пам'ятати про можливість двохмоментного розриву селезінки. Летальність при пораненнях селезінки в основному залежить від тяжкості поєднаних пошкоджень [4, 29, 31].

Успіх лікування поранень підшлункової залози (ПЗ) залежить від ранньої діагностики, глибини пошкодження ПЗ і вчасно розпочатого хірургічного лікування [6, 32]. У білышості спостережень пошкоджень ПЗ виконують тільки зовнішне дренування області пошкодження і вводять інгібітори ферментів і розчин новокаїну під капсулу залози.

Ключові принципи лікування пошкоджень ПЗ: зупинка кровотечі; видалення нежиттездатної тканини залози; по можливості збереження 20 - 50\% функціонуючої тканини органа; забезпечення адекватного внутрішнього або зовнішнього дренування. Паралельно оцінюють наявність пошкодження інших органів, особливо ДПК, яка часто пошкоджується разом з ПЗ, ступінь руйнування паренхіми і залучення головної протоки ПЗ. Клінічними критеріями пошкодження головної протоки ПЗ є: візуальне виявлення пошкодження протоки, повний розрив ПЗ, розрив розмі- ром більше половини діаметра залози, центральна ії перфорація і розтрощення. При пошкодженнях тіла і хвоста ПЗ зазвичай виконують їі дистальну резекцію $[2,6,33]$.

Успіх у лікуванні пошкоджень великих кровоносних судин черевної порожнини забезпечують: швидка доставка пораненого в лікувальний заклад, термінова лапаротомія і зупинка кровотечі $[5,10,16,32]$, негайний початок інфузійно-трансфузійної терапії та швидке поповнення об'єму циркулюючої крові [14, 30].

Одним із сучасних підходів до лікування військовослужбовців з вогнепальними пораненнями живота є багатоетапна хірургічна тактика «damage control», яка набула поширення як в умовах цивільних травмоцентрів [34], так і в умовах бойових дій в Іраку і Афганістані в медичній службі військ коаліції $[30,35,36]$. Тактика «damage control» трьохетапна. На першому етапі виконують операцію в скороченому обсязі, метою якої є зупинка внутрішньочеревної кровотечі і припинення забруднення вмістом порожнистих органів черевної порожнини. Після чого черевну порожнину тимчасово закривають або накладають лапаростому. Другим етапом проводять інтенсивну терапію до стабілізації життєво важливих функцій організму. На третьому етапі виконують повторне оперативне втручання для завершення корекції пошкоджених органів [5, 26, 31, 37]. Тактика програмованих релапаротомій раніше була запропонована для контролю життездатності пошкоджених органів (операції «second look») i контролю перебігу перитоніту (санаційні релапаротоміі). Однак у віддаленому періоді у разі застосування тактики багатоетапних втручань виникає ряд ускладнень, зокрема, вентральні грижі, кишкові нориці [23, 24].

У публікаціях, на які вище є посилання, наведено великий обсяг фактичного матеріалу, але всі ці дані характеризують або надання допомоги військовослужбовцям, пораненим у живіт, на певному етапі медичної евакуації, або певний вид поранення. Узагальнених даних про сучасні вогнепальні поранення живота, особливості пошкодження кожного органу черевної порожнини і виконані оперативні втручання, а також остаточних результатів лікування поранень живота загалом у літературі немає.

\section{Висновки}

1. Результат лікування поранень живота залежить від якості організації лікувально-евакуаційного процесу 3 урахуванням принципу «золотої години».

2. Оптимізація діагностичної програми з обов'язковим застосуванням FAST-протоколу дає змогу уникнути необгрунтованих інвазивних втручань і скоротити строки встановлення діагнозу.

3. Успіх лікування поранених з пошкодженнями магістральних судин черевної порожнини прямо залежить від швидкої їх доставки в лікувальний заклад.

4. Виконання органозберігаючих операцій при пораненнях селезінки в умовах сучасних бойових дій небезпечне для життя пораненого, якого транспортують на наступні рівні надання медичної допомоги.

5. При пошкодженнях правої половини товстої кишки допустимо зашивання дефекту ії стінки з екстраперитонізацією зашитої ділянки або виконання правобічної ге- 
міколектомії з формуванням ілеотрансверзоанастомоза. При пошкодженнях лівої половини товстої кишки перевагу слід віддавати обструктивній резекції з формуванням протиприродного заднього проходу або зашиванню дефекту з превентивною колостомією.

6. В основі хірургічного лікування має лежати принцип диференційованого підходу із застосуванням на етапах медичної евакуації тактики «damage control».

\section{References}

1. Dubose JJ, Scalea TM, Holcomb JB, Shrestha B, Okoye O, Inaba K, et al. Open abdominal management after damage-control laparotomy for trauma: A prospective observational American Association for the Surgery of Trauma multicenter study. J Trauma. 2013;74(1):113-22. doi: 10.1097/TA.0b013e31827891ce.

2. Kapan M, Onder A, Oguz A, Taskesen F, Aliosmanoglu I, Gul M, Tacyildiz I. The effective risk factors on mortality in patients undergoing damage control surgery. European Review for Medical and Pharmacological Sciences. 2013;17(12):1681-7. PMID: 23832738.

3. Lamb CM, Garner JP. Selective non-operative management of civilian gunshot wounds to the abdomen: A systematic review of the evidence. Injury. 2014 Apr;45(4):659-66. doi: 10.1016/j.injury.2013.07.008.

4. Belyy VYa, Zarutskiy YaL, Zhovtonozhko AI, Aslanyan SA. Ocherki boyevoy travmy zhivota. Kyiv: «MP Lesya»; 2016. 212 s. [In Russian].

5. Zarutskyi YaL, Zaporozhan VM, Bilyi VYa, Denysenko VM, Aslanyan SA, Bohdan IS. Voienno-polova khirurhiia. Odeskyi meduniversytet; 2016. 415 s. [In Ukrainian].

6. Herasymenko OS. Khirurhichne likuvannya boyovykh ushkodzhen zhyvota $\mathrm{v}$ raioni provedennia antyterorystychnoi operatsii. Odeskyi medychnyi zhurnal. 2017;3(161):34-8. [In Ukrainian].

7. Khomenko IP, Yenin RV, Tertyshnyi SV. Mozhlyvosti endovideokhirurhii v likuvanni poranen i travm zhyvota na druhomu rivni medychnoi dopomohy u zoni provedennia antyterorystychnoi operatsii. Odeskyi medychnyi zhurnal. 2017; (3):27-31. [In Ukrainian].

8. Zarutskyi YaL, Shudrak AA. Vkazivky z voienno-polovoi khirurhii. Kyiv: SPD Chaplins'ka NV; 2014. 396 s. [In Ukrainian].

9. Zhian Uk, Baldan M. Abdominal injury. Military field surgery. Zeneva. 2013;26:455-526.

10. Samokhvalov IM, Kotenko PK, Severin VV. Problemy organizatsii okazaniya khirurgicheskoy pomoshchi ranenym v sovremennoy voyne: okazaniye meditsinskoy pomoshchi i lecheniya legkoranenykh v vooruzhennom konflikte. Voyenno-meditsinskiy zhurnal. 2013;334(1):4-8. [In Russian].

11. Hornez E. Complex abdominal penetrating wounds by war missiles.

French experience resulting from modern conflicts (Afghanistan, Africa): 3-rd Pan-European Congress of Military Medics. Belgrad. 2014: 11.

12. Leite $\mathrm{S}$, Taveira-Gomes A, Sousa H. Visceral injury in abdominal trauma: A retrospective study. Acta Médica Portuguesa. 2013;26(6):725-30.

13. Zonies D, Eastridge B. Combat management of splenic injury: Trends during a decade of conflict. J. Trauma Acute Care Surg. 2012;73(2 Suppl 1):71-4. doi: 10.1097/TA.0b013e31826061fc

14. Zavrazhnov A. Povrezhdeniya zhivota. Skoraya meditsinskaya pomoshch'. Natsional'noye rukovodstvo. Moskva: «GEOTAR-Media»; 2015; 513-9. [In Russian].

15. Samokhvalov I, Zhabin A, Grebnev A. Sokrashchennoye ul'trazvukovoye issledovaniye $\mathrm{v}$ khirurgii povrezhdeniy zhivota: metodika i vozmozhnosti klinicheskogo primeneniya. Voyenno-meditsinskiy zhurnal. 2014;335(4):30-6. [In Russian].

16. Svítlichniy YeV, Grechanik OÍ. Ul’trazvukova díagnostika travmi ta íi uskladnen' /Navchal'niy posíbnik/ Kyiv: SPD Chaplins'ka NV; 2016. 215 s. [In Ukrainian].

17. Reginelli A, Russo A, Maresca D, Martiniello C, Cappabianca S, Brunese L. Imaging Assessment of Gunshot Wounds. Semin Ultrasound CT MR. 2015;36(1):57-67. doi: 10.1053/j.sult.2014.10.005.

18. Russell T, Crawford P. Ultrasound in the austere environment: A review of the history, indications, and specifications. Military medicine. 2013;178(1):21-8. PMID:23356114.

19. Schleder S, Dendl L, Ernstberger A, Nerlich M, Hoffstetter P, Jung E, et al. Diagnostic value of a hand-carried ultrasound device for free in- tra-abdominal fluid and organ lacerations in major trauma patients Emerg Med J. 2013;30(3):1-5. doi: 10.1136/emermed-2012-201258.

20. Smith I, Naumann D, Marsden M, Ballard M, Bowley D. Scanning and war utility of FAST and CT in the assessment of battlefield abdominal trauma. Ann Surg. 2015;262(2):389-96. doi: 10.1097/ SLA.0000000000001002.

21. Inaba K, Okoye O, Rosenheck R, Melo N, Branco B, Talving P, Lam L, Reddy S, Salim A, Demetriades D. Prospective evaluation of the role of computed tomography in the assessment of abdominal stab wounds. JAMA Surg. 2013;148(9):810-6. doi: 10.1001/jamasurg.2013.2521.

22. Mitchell T, Hutchison T, Becker T, Aden J, Blackbourne L, White C. Nontherapeutic laparotomy in American combat casualties: A 10-year review. J. Trauma Acute Care Surg. 2014;77(3):172-5. doi: 10.1097/ ta.0000000000000367.

23. Navsaria PH, Nicol AJ, Edu S, Gandhi R. Selective nonoperative managementin 1106 patients with abdominal gunshot wounds: conclusions on safety, efficacy, and the role ofselective CT imaging in a prospective single-center study. Ann Surg. 2015;261(4):760-4. doi: 10.1097/ SLA.0000000000000879.

24. Mizrahi H, Geron N, Nicola A. Laparoscopic treatment of duodenal injury caused by gunshot. Injury. 2014;45(5): 916-7. doi: 10.1016/j. injury.2014.01.013.

25. Felichano D, Mattoks K, Mur E. Dvenadtsatiperstnaya kishka i podzheludochnaya zheleza. Travma: Rukovodstvo $\mathrm{v} 3 \mathrm{t} /$ perevod s angl pod red. Yakimova L, Matveyeva N. Moskva: Izd-vo Panfilova, Binom, Laboratoriya znaniy. 2013;3(869-890). [In Russian].

26. Sukhodolya A. Khirurgicheskoye lecheniye povrezhdeniy dvenadtsatiperstnoy kishki. Khirurgiya. 2014;7:17-20. [In Russian].

27. Ordonez C, García A, Parra M, Scavo D, Pino L, Millán M, et al. Complex penetrating duodenal injuries: Less is better. J. Trauma Acute Care Surg. 2014;76(5):1177-83. doi: 10.1097/TA.000000000000214.

28. Garst G, Geoffrey C, Miller, Heidi J, Leung, Pak S. Delayed duodenal injury following abdominal gunshot wound. J. Trauma Acute Care Surgery. 2014;77(5):796-7. doi: 10.1097/TA.0000000000000449.

29. Mutafchiyski V, Popivanov G, Kjossev K. Medical aspects of terrorist bombings - a focus on DCS and DCR. Military Medical Research. 2014;1:13-8. doi: 10.1186 / 2054-9369-1-13.

30. Bradley M, Dubose J, Scalea T, Holcomb J, Shrestha B, Okoye O, et al. Independent predictors of enteric fistula and abdominal sepsis after damage control laparotomy. Results from the prospective AAST open abdomen registry. JAMA Surg. 2013;148(10):947-54. doi: 10.1001/jamasurg.2013.2514.

31. Velmahos G. Obodochnaya i pryamaya kishka. Travma: Ruk-vo v 3 t. / Feliciano D, Mattoks K, Mur E. per. s angl. pod red. Yakimova L, Matveyeva N. Moskva: Izdatelstvo Panfilova, Binom, Laboratoriya znaniy. 2013;3:893-909. [In Russian].

32. Glasgow S, Sean C, Heafner, Thomas A, Watson J, Devin B, et al. Initial management and outcome of modern battlefield anal trauma. Diseases of the Colon \& Rectum. 2014;57(8):1012-8. doi: 10.1097/ DCR.0000000000000141

33. Langan N, Eckert M, Martin M. Changing patterns of in-hospital deaths following implementation of damage control resuscitation practices in US forward military treatment facilities. JAMA Surg. 2014;149(9):90412. doi: 10.1001/jamasurg.2014.940.

34. Diebel L. Zheludok i tonkaya kishka. Travma: Ruk-vo v 3 t. / Feliciano D, Mattoks K, Mur E. per. s angl. pod red. Yakimova L, Matveyeva N. Moskva: Izdatelstvo Panfilova, Binom, Laboratoriya znaniy. 2013;3:843-66. [In Russian].

35. Kashtal'yan M, Khomenko Í, Herasymenko O, Shapovalov V, Yenin R. Khírurgíchne líkuvannya vognepal'nikh poranen' tovstoíyi kishki. Problemi víys'kovoï okhoroni zdorov'ya: zbírnik naukovikh prats' Ukraïns'koï víys'kovo-medichnoï akademíi. Kyiv. 2017;48:64-70. [In Ukrainian].

36. Ball C. Current management of penetrating torso trauma: nontherapeutic is not good enough anymore. J Can Chir, 2014;57(2):36-43. doi: 10.1503/cjs.026012

37. Fadbian T, Bee T. Pechen' i biliarnyy trakt. Travma: Ruk-vo v 3 t. / Feliciano D, Mattoks K, Mur E. per. s angl. pod red. Yakimova L, Matveyeva N. Moskva: Izdatelstvo Panfilova, Binom, Laboratoriya znaniy. 2013;3:789-815. [In Russian]. 